\title{
Correlation between Obesity and Contraceptive Method on Estrogen and Progesterone Receptors and Human Epidermal Growth Factor Receptor-2 Expression among Breast Cancer Patients in Dr. Moewardi Hospital, Surakarta
}

\author{
Silvia Ari Agustina, Liberty Barokah \\ Study Program in Midwifery, School of Health Sciences Achmad Yani, Yogyakarta
}

\begin{abstract}
Background: Breast cancer is the number 2 cancer in Indonesia after cervical cancer. Breast cancer increases every year. The formation of breast cancer is stimulated by various factors such as obesity and a history of family planning. In breast cancer there are three important receptors, namely estrogen (ER) receptors, progesterone receptors (PR), and HER-2/Neu. The purpose of this study was to determine the association of obesity and history of family planning with the estrogen hormone receptor (ER), progesterone hormone receptor (PR), and HER-2/Neu expression in breast cancer patients in the dr. Moewardi Hospital in Surakarta, Central Java.

Subjects and Method: This was an analytic observational study carried out at Dr. Moewardi Hospital, Surakarta, Central Java. A sample of 117 pre- and post-menopausal women who performed examinations at the oncology surgical clinic at Dr. Moewardi hospital, Surakarta was selected by total sampling. The dependent variables were estrogen and progesterone receptors and HER-2/Neu expressions. The independent variables were obesity and history of contraceptive method. Data was obtained from medical record and analyzed by a multiple logistic regression.

Results: Obesity ( $\mathrm{OR}=0.29 ; 95 \% \mathrm{CI}=0.13$ to $0.68 ; \mathrm{p}=0.004)$ reduced estrogen hormone receptors and it was statistically significant. History of contraceptive method $(\mathrm{OR}=1.18$; $95 \% \mathrm{CI}=$ 0.55 to $2.52 ; \mathrm{p}=0.680$ ) increased estrogen hormone receptors but it was not statistically significant. Obesity $(\mathrm{OR}=0.41 ; 95 \% \mathrm{CI}=0.18$ to $0.96 ; \mathrm{p}=0.040)$ and history of contraceptive method $(\mathrm{OR}=0.41 ; 95 \% \mathrm{CI}=0.19$ to $0.88 ; \mathrm{p}=0.022)$ reduced progesterone hormone receptors. Obesity and history of contraceptive method increased Her-2/Neu expression.

Conclusion: Obesity reduces estrogen hormone receptors. History of contraceptive method increases estrogen hormone receptors. Obesity and history of contraceptive method reduce progesterone hormone receptors. Obesity and history of contraceptive method increase Her-2/Neu expression.
\end{abstract}

Keywords: Obesity, contraceptive method, esterogen, progesterone hormones, Her-2/neu

\section{Correspondence:}

Silvia Ari Agustina. Study Program in Midwifery, School of Health Sciences Achmad Yani, Yogyakarta. Jl. Ringroad Barat Ambarketawang, Gamping, Sleman, Yogyakarta. Phone: (0274) 4342000. Email:silvia_ari99@yahoo.com

\section{BACKGROUND}

Cancer was one of the causes of death throughout the world. WHO data in 2012 showed that around 8.2 million deaths were caused by cancer. In Indonesia, cancer was the number 2 cause of death in the world by $13 \%$ after cardiovascular disease (RI Ministry of Health, 2015). In general, breast cancer attacked women, the possibility of breast cancer in men was very small, which was 1: 1000 (Mulyani, 2013).

Factors at risk of increasing breast cancer were age, genetics, alcohol consumption, smoking, lack of activity, history of family planning, estrogen hormones, and obesity (Kresnawan, 2012). Increased body weight or Body Mass Index (BMI) can increase the risk of breast, colon, prostate, 
endo-metrium, kidney, and gall bladder cancers (Hamdy et al., 2013). Obesity factors can increase the risk of cancer by 30\% (Kresnawan, 2012).

The use of hormonal contraception can lead to increased exposure to estrogen and progesterone hormones which can cause cell proliferation in the breast glands and inhibition of the apoptotic process so that it increased the risk of breast cancer (Nissa et al., 2017).

A study by Soroush et al. (2016), stated that more than 4 years of pill use of hormonal contraception can increase breast cancer risk by 1.52 times.

Estrogen was thought to increase breast cancer risk factors. In breast tissue, estrogen would stimulate growth and differentiation of the epithelium, induce mitotic activity of cells, stimulate growth of connective tissue and fat deposits in the breast. High estrogen levels were very influential on cancer growth in a person's breast (Guyton and Hall, 2008).

Breast cancer has estrogen, progesterone, and HER-2 hormone receptors. Positive hormone receptors in breast cancer patients represent the majority of breast cancers in the world. About $60 \%$ to $75 \%$ of women with breast cancer with estrogen positive receptors (ER + ) and $65 \%$ of these cancers also have positive progesterone receptors (PR+) (Macmillan Cancer Support, 2011).

Doctor Elysa, Public Relations Department of the Dr Moewardi Hospital reported, that there were over 500 cancer patients at Dr Moewardi Hospital every month. The highest were cervical cancer and breast cancer. The number was high and the increase reached 50\% (Daryono, 2016). Data from Dr. Moewardi Hospital, reported the number of breast cancer cases in 2014, namely, total hospitalization of 3,583 patients and 9,909 of outpatients, while in 2015 the number of hospitalized patients increased to 4,596 patients and 13,221 outpatients.

\section{SUBJECTS AND METHOD}

\section{Study Design}

This study was an observational analytic conducted in the Surgical Oncology Section, Dr. Moewardi, Surakarta, Central Java.

\section{Population and Sample}

A sample of 117 pre- and post-menopausal women who performed examinations at the oncology surgical clinic at dr. Moewardi hospital, Surakarta, Central Java, was selected by purposive sampling. The inclusion criteria were pre and post-menopausal cancer patients at the Poly Surgical Oncology, and patients with no liver and/or kidney disorders. Exclusion criteria were incomplete medical records of breast cancer patients.

\section{Study Variable}

Dependent variables were estrogen and progesterone receptors and expression of HER-2/Neu. The independent variables were obesity and family history.

\section{Study Instruments}

Data on body weight, height, and results of hormone receptor and Her-2/Neu examination with Immunohistochemistry (CPI) of breast tissue biopsy were obtained from medical records at Dr. Moewardi hospital, Surakarta.

\section{Data Analysis}

Analysis of data was using multiple logistic regression analysis.

\section{RESULTS}

The majority of patients with breast cancer after menopause (54.7\%), have low education $(41 \%$ graduated from elementary school), housewives (72.6\%), obesity (56.4\%), hormonal contraception (70.9\%), estrogen hormonal receptor of positive 
status $(56.4 \%)$, positive progesterone hormone receptor status (52.1\%),
Her-2/ positive Neu receptor hormonal status (50.4\%).

Table 1. The results of the logistic regression analysis of the relationship of obesity and history of family planning with the estrogen hormone receptor

\begin{tabular}{lcccc}
\hline \multirow{2}{*}{ Dependent Variables } & \multirow{2}{*}{ OR } & \multicolumn{2}{c}{ CI 95\% } & p \\
\cline { 3 - 4 } & & Lower limit & Upper limit & 0.004 \\
Obesity & 0.29 & 0.13 & 0.68 & 0.680 \\
History of FP & 1.18 & 0.55 & 2.52 & \\
P value Reg. Log. $=$ 0.012 & & & & \\
Nagelkerke R-Square $=9.8 \%$ & & & \\
Hosmer and Lemesshow Test Chi Square 2.07 & & \\
p=0.355 & & & \\
\hline
\end{tabular}

Table 1 showed the results of the logistic regression analysis of the relationship of obesity and history of family planning to the estrogen hormone receptor. Table 1 showed that obesity $(\mathrm{OR}=0.29 ; 95 \% \mathrm{CI}=$ 0.13 to $0.68 ; p=0.004$ ) decreased estrogen

Table 2.The results of the logistic regression analysis of the relationship of obesity and history of family planning with progesterone hormone receptors

\begin{tabular}{lcccc}
\hline \multirow{2}{*}{ Dependent Variables } & \multirow{2}{*}{ OR } & \multicolumn{2}{c}{ CI 95\% } & p \\
\cline { 3 - 4 } & & Lower limit & Upper limit & \\
Obesity & 0.41 & 0.18 & 0.96 & 0.040 \\
History of FP & 0.41 & 0.19 & 0.88 & 0.022 \\
p value Reg. Log. $=0.010$ & & & \\
Nagelkerke R-Square = 10\% & & & \\
Hosmer and Lemesshow Test Chi Square $=0.049$ & \\
p= 0.976
\end{tabular}

Table 2 showed the results of the logistic regression analysis of the relationship of obesity and history of family planning to the progesterone hormone receptor. Table 2 showed that obesity $(\mathrm{OR}=$

Table 3.The results of the logistic regression analysis of the relationship of obesity and family history to the expression of HER-2 / Neu

\begin{tabular}{|c|c|c|c|c|}
\hline \multirow{2}{*}{ Dependent Variables } & \multirow{2}{*}{$\mathbf{O R}$} & \multicolumn{2}{|c|}{$95 \% \mathrm{CI}$} & \multirow[b]{2}{*}{$\mathbf{p}$} \\
\hline & & Lower limit & Upper limit & \\
\hline Obesity & 1.16 & 0.52 & 2.59 & 0.710 \\
\hline History of contraceptive method & 1.19 & 0.58 & 2.47 & 0.635 \\
\hline \multicolumn{5}{|l|}{$\mathrm{P}$ value Reg. $\mathrm{Log} .=0.841$} \\
\hline \multicolumn{5}{|l|}{ Nagelkerke R-Square= 4\% } \\
\hline \multicolumn{5}{|c|}{ Hosmer and Lemesshow Test Chi Square $=1.26$} \\
\hline $\mathrm{p}=0.532$ & & & & \\
\hline
\end{tabular}

Table 3 showed the results of the logistic regression analysis of the relationship of obesity and history of family planning to
$0.41 ; 95 \% \mathrm{CI}=0.18$ to $0.96 ; \mathrm{p}=0.040)$ and family history (OR $=0.41 ; 95 \% \mathrm{CI}=0.19$ to $0.88 ; \mathrm{p}=0.022$ ) decreased the progesterone hormone receptor. hormone receptors and it was statistically significant. Family planning history (OR = $1.18 ; 95 \% \mathrm{CI}=0.55$ to $2.52 ; \mathrm{p}=0.680$ ) increased estrogen hormone receptors but it was not statistically significant. 
$(\mathrm{OR}=1.19 ; 95 \% \mathrm{CI}=0.58$ to $2.47 ; \mathrm{p}=0.635)$ increased Her-2/Neu expression but it was statistically insignificant.

\section{DISCUSSION}

The results showed the percentage of women suffering from breast cancer was higher at postmenopausal age (54.7\%). This was consistent with the theory which stated that post-menopausal women have a higher risk of breast cancer than premenopausal women due to estrogen levels in the blood (Sastrawinata, 2007). The results of this study were in accordance with the research of Rianti and Emy et al., (2012), which stated that women aged $>50$ years old were 5.8 times more likely to develop breast cancer than women $<50$ years old.Breast cancer begins to develop rapidly at the age of 40-49 years old before women enter the age of 50 years old and above. The risk of breast cancer developed up to the age of 50 years old with an odds ratio of 1 in 50 women. The possibility of developing breast cancer increased with age, and more than $75 \%$ of breast cancers were diagnosed in women aged 40 years old and over. Breast cancer was rare in women under 30 years old (Lincoln and Wilensky, 2008).

The results also showed that most cancer patients were hormonal FP acceptors (70.9\%). This result was in line with the research of Nissa PAE et al. (2017), which stated that the use of hormonal FP can cause the risk of breast cancer. The composition of the progestin injection consists of $150 \mathrm{mg}$ of Medroxy progesterone Asetate and $200 \mathrm{mg}$ of Depot Norestisterone Enantat. With composition and prolonged use it would cause the risk of breast cancer (Saifuddin et al., 2003).

The other result was that breast cancer sufferers were mostly obese (56.4\%). After menopause, fat tissue was the most important source of estrogen, where estrogen levels in postmenopausal women were higher by 50 to 100 percent compared to women of normal/ideal weight. Fat women have higher estrogen levels compared to thin women due to increased peripheral aromatization. This was related to SHBG levels, where a decrease in SHBG in obesity would increase the bioavailability of circulating estradiol, so obese women have a relatively higher risk of facing breast cancer (Lorincz and Sukumar, 2006).

The results of this study were consistent with the research of Green et al., (2012), which stated that obesity breast cancer patients have a strong relationship with ER (+) expression compared to ER (-) expression. Obesity factors may have a significant role in ER expression and can have an effect on the progression and proliferation of breast cancer cells.

The results of this study were in line with the research of Widiasari E (2016), which stated that the use of injection of Depot-Medroxy-progesterone Acetate (DMPA) has no significant relationship with the increase in estradiol levels. The results of Setiowati et al., (2016), suggested that there was a meaningful relationship between the use of hormonal family planning and the incidence of breast cancer. The consumption of estrogen from the outside until now was suspected of increasing the risk of breast cancer. The commonly used hormone combination pill was still considered safe and did not increase the risk of breast cancer.

Users of hormonal contraception showed an increased risk of breast cancer, compared to those who did not use it. But the incidence of cancer was not only caused by the use of birth control pills. Many other influential factors include; obesity, premature menstruation, history of breast abnormalities, family history of breast cancer, 
and not being physically active (Anakku, 2014).

Obesity which was associated with an increased increase in estrogen in human mammary epithelial cells (HMECs) increased the risk of breast cancer. The results of this study indicated that there was a significant relationship between obesity and a history of family planning with progesterone hormone receptors in breast cancer patients. The results of this study were not in line with Rahmawati (2016) who stated that the use of hormonal contraception did not correlate with the expression of immunochemistry of progesterone and estrogen receptors. Women with BMI> 30 during adulthood have a 3 -fold relative risk of developing tumors with $\mathrm{ER}+\mathrm{PR}+$. In addition to receptor status that has a risk of breast cancer, age at first birth, postmenopausal obesity, and estrogen-progestin hormone therapy were stronger risk factors for positive-receptor breast cancer (Rosenberget al., 2006; Lordet al., 2008).

The patient was said to have positive HER-2 if a large number of HER-2 tumors are found. Positive HER-2 cancer was known as an aggressive form of breast cancer and has a worse estimate of disease than patients with negative HER-2. It was estimated that one in four to five patients with late stage breast cancer has positive HER-2 (Seidenfeld et al., 2008; Slamon et al., 1989; Thor et al., 1989). Amplification of the Her-2/neu gene was another prognostic and predictive factor for breast cancer. About 20\% of breast cancer patients have amplification of the Her 2 Neu gene which lead to overexpression glycogen protein (Burstein et al, 2008).

The results of this study indicated that obesity and history of family planning increase HER-2/Neu expression in breast cancer patients but it was not statistically significant.
The difference between the results of the study and the theoretical basis can occur, presumably because there was no increase in proliferation and metastasis due to over expression or amplification of the HER-2 gene. In addition, because it was estimated that amplification only occurred around 20-30\% in breast cancer cases. Over HER-2 gene expression was more common in high-grade breast cancer (abnormally fast cell growth) or advanced clinical stage compared to low grade (slow abnormal cell growth) or low clinical stage (Tang et al., 2006).

The incompatibility of the results of the research with the theory in this study was because the sample of breast cancer patients with TNM clinical stage data was not only from advanced data in all receptor status subgroups, there was a possibility that HER-2 gene amplification which would result in proliferation and metastasis cancer cells. This result was supported by a theoretical basis for the imbalance of the hormones progesterone and estrogen which were actually used for hormonal contraceptives.

There were two theories that discuss how estrogen and progesterone cause breast cancer, namely the risk of cell mutation when division increased because cell proliferation by increasing estrogen and progesterone also increased (Prawirohardjo $\mathrm{S}$, 2011) and estrogen and progesterone stimulate the growth of breast cancer peak cells (Kresno, 2012).

\section{AUTHOR CONTRIBUTIONS}

Silvia Ari Agustina collected the data and wrote the manuscript. Liberty Barokah did data analysis.

\section{CONFLICT OF INTEREST}

We declare that there is no conflict of interest. 


\section{FUNDING AND SPONSORHIP}

There is no external fund and sponsorship.

\section{ACKNOWLEDGEMENT}

We would like to thank oncology surgical clinic, Dr. Moewardi hospital, Surakarta, Central Java for giving permission to collect the data.

\section{REFERENCE}

Anakku (2014). Hormon Biang Keladi Kanker Payudara. Redaksi Majalah Anaku. Retrieved from http://www.anakku.net/hormon-biang-keladikanker-payudara.html.

Burstein HJ, Harris JR, Morrow M (2008). Malignant tumors of the breastin cancer principles \& practice of oncology. Devita VT, Lawrence TS, Rosenberg SA. (Wolters Kluwer Lippincott: Williams and Wilkins): 1606-54.

Daryono (2016). Tiap Bulan 500 Penderita Kanker Berobat ke RSUD Dr Moewardi. Retrieved from http://www.timlo.net/baca/68719656366/tiapbulan-50o-penderita-kanker-berobatke-rsud-dr-moewardi/.

Green LE, Dinh TH, Smith RA (2012). An estrogen model: The relationship between body mass index, menopausal status, estrogen replacement therapy, and breast cancer risk. Hindawi Publishing Corporation Computational and Mathematical Methods in Medicine: 792375: 1-8. doi: 10.1155/2012/792375

Guyton AC, Hall JE (2008). Buku Ajar Fisiologi Kedokteran. Edisi 11. EGC. Jakarta

Hamdy et al., (2013). Obesity. Retrieved from www.medscape.com, 2013.

Kemenkes RI (2015). Situasi Penyakit Kanker. Buletin Jendela Kementerian Kesehatan RI. Jakarta
Kresnawan T (2012). Mengatur Makanan untuk Pencegahan danTerapi Kanker Payudara. Instalasi Gizi RSCM. Retrieved from http://gizi.depkes.go.id/wpcontent/uploads/2012/05/ME NGATUR-MAKANAN-KANKERPAYUDARA.pdf.

Kresno, Boedina S (2012). Ilmu Dasar Onkologi. Badan Penerbit FKUI. Jakarta.

Lincoln J, Wilensky (2008). Kanker payudara diagnosis dan solusinya. Prestasi Pustakaraya.Jakarta.

Lord, et al. (2008). Breast cancer risk and hormone receptor status in older women by parity, age of first birth, and breastfeeding: A case-control study. American Association for Cancer Research. Cancer Epidemiol Biomarkers Prev. 17(7).

Lorincz AM, Sukumar S (2006). Molecular linked between obesity and breast cancer. Retrieved from http://erc.endocrinologyjournals.org/cgi/content/full/13/2/279.

Macmillan Cancer Support (2011). Staging, grading, and receptors for breast cancer. Dalam: Macmillan Cancer Support, Understanding Breast Cancer.

Mulyani S (2013). Menopause akhir siklus menstruasi pada wanita di usia pertengahan. Nuha Medika.Yogyakarta

Nissa PAE, et al. (2017). Kontrasepsi hormonal sebagai faktor risiko kanker payudara di RSUD Al-Ihsan Bandung. Bandung Meeting on Global Medicine \& Health (BaMGMH), 1(1).

Prawirohardjo S (2011). Buku ilmu kandungan sarwono edisi ketiga. Jakarta: PT. Bina Pustaka Sarwono Prawirohardjo

Rahmawati A (2016). Hubungan antara penggunaan hormon eksogen terutama progesteron dengan ekspresi reseptor progesteron, estrogen, dan VEGF Pada Meningioma Orbito- 
kranial Wanita. Electronic Theses and Dissertation (ETD) UGM: Yogyakarta

Rianti E, et al. (2012). Faktor-faktor yang berhubungan dengan risiko kanker payudara. Jurnal Health Quality, 3(1): 10

Rosenberg LU, Einarsdottir K, Friman EI, Wedren S, Dickman PW, Hall P, Magnusson (2006). Risk factors for hormone receptor-defined breast cancer in postmenopausal women. Association for Cancer Research. Cancer Epidemiol Biomarkers Prev. 15(12).

Saifuddin AB, et al. (2003). Buku panduan praktis pelayanan kontrasepasi. Jakarta: Yayasan Bina Pustaka Sarwono Prawirohardjo.

Sastrawinata S (2007). Obstetri patologi ilmu kesehatan reproduksi. Edisi 2. EGC. Jakarta.

Seidenfeld J, Samson DJ, Rothenberg BM, Bonnel CJ, Ziegler KM, Aronson N (2008). HER-2 Testing to Manage Patients with Breast Cancer or Other Solid Tumors. Evidence Report.

Setiowati DAI, Tanngo EH, Soebijanto RI. (2016. Hubungan antara Pemakaian kb hormonal dengan kejadian kanker payudara di poli Onkologi Satu Atap RSUD Dr. Soetomo, Februari-April
2015. Indonesian Journal of Cancer. 10(1): 11-17

Slamon DJ, Godolphin W, Jones LA, et al. (1989). Studies of the HER2/neu proto-oncogene in human breast and ovarian cancer. Science. 244: 707-712

Soroush A, Farschian N, Komasi S, Izadi N, Amirfrard N, Shahmohammadi A (2016). The roles of oral contraceptive pills on increased risk of breast cancer in Iranian Populations. J Cancer Prev. 21(4):294-301

Tang $\mathrm{P}$, Wang $\mathrm{X}$, Schiffhauer L, Wang J,Bourne P, Yang Q, et al. (2006). Expression patterns of ER- $\alpha$, PR, HER-2/neu, and EGFR in different cell origin subtypes of high grade and non-high grade ductal carcinoma in situ. Annals of Clinical \& Laboratory Science. 36(2).

Thor AD, Schwartz LH, Koerner FC, et al. (1989). Analysis of c-erbB-2 expression in breast carcinomas with clinical follow-up. Cancer Res. 49: 7147-7152

Widiasari E (2016). Hubungan penggunaan injeksi depot-medroxyprogesterone acetate (DMPA) dengan kadar estradiol pada penderita kanker payudara. Tesis Fakultas Kedokteran Spesialis Ilmu Bedah UNS: Surakarta. 